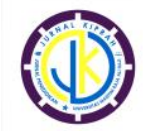

e-ISSN: 2580-6947

p-ISSN: $2354-7278$

http://ojs.umrah.ac.id/index.php/kiprah/index

\title{
PENINGKATAN PRESTASI BELAJAR EKONOMI MENGGUNAKAN STRATEGI TUTOR SEBAYA DAN SNOWBALL THROWING PADA PESERTA DIDIK SMA N 15 BATAM TAHUN PELAJARAN 2017/2018
}

\author{
Wiji Utami
}

\author{
SMA N 15 Batam, Kota Batam, Kepulauan Riau 29466, Indonesia
}

Pengiriman: 1 Februari 2019; Diterima: 13 Mei 2019; Publikasi: 28 Juli 2019

\begin{abstract}
Abstrak
Dari pengamatan awal bahwa nilai peserta didik masih rendah, diperoleh rata-rata awal nilai 68,41 dengan ketuntasan belajar 33,33\%. Peneliti berupaya mengganti metode konvensional menjadi metode yang konstruktivis menggunakan strategi tutor sebaya dan Snowball Throwing. Penelitian tindakan kelas yang dilakukan yang bertujuan untuk meningkatkan prestasi belajar siswa di kelas XI IPS 1 SMA N 15 Batam dilakukan dalam dua siklus dengan tahapan masing-masing mulai perencanaan, dilanjutkan dengan pelaksanaan, observasi dan refleksi. Setelah data dikumpulkan menggunakan tes dan dianalisis dengan analisis deskriptif, diperoleh peningkatan prestasi belajar pada siklus I menjadi 72,10 dengan ketuntasan belajar 48,72\% dan pada siklus II sudah meningkat sesuai harapan yaitu rata-rata kelas yang dicapai 83,20 sudah melebihi KKM mata pelajaran 75 di sekolah ini dengan ketuntasan belajar $89,74 \%$ yang melebihi tuntutan indikator keberhasilan penelitian yaitu $85 \%$. Kesimpulan yang bisa disampaikan adalah penggunaan strategi tutor sebaya dan Snowball Throwing dalam proses pembelajaran dapat meningkatkan prestasi belajar siswa.
\end{abstract}

Kata kunci : strategi tutor sebaya; snowball throwing; prestasi belajar

\begin{abstract}
This study is a classroom action research aiming to improve student achievement in the XI IPS 1 class of SMA N 15 Batam. The research was conducted in two cycles with each stage startingwith planning, followed by implementation, observation and reflection. Based on initial observation, students gained lower everage 68,41 with $33,33 \%$ completeness. Regarding that situation, researcher attempt to replace the conventional method to Constructivist methods by using peer tutoring strategies and Snowball Throwing. Data was collected using tests and analyzed by descriptive analysis, the first cycle, the everage increasing to 72.10 with $48.72 \%$ learning completeness and in the second cycle had increased as expected, the class average achieved 83.20 had exceeded the KKM 75 subjects in this school with learning completeness $89.74 \%$ which exceeds the demands of the indicator of research success which is $85 \%$. The conclusion that can be conveyed is the use of peer tutoring strategies and Snowball Throwing in the learning process can improve student learning achievement.
\end{abstract}

Keywords : peer tutorial strategy; snowball throwing; student achievement

\section{PENDAHULUAN}

Pendidikan mempunyai peranan yang sangat penting dalam perkembangan seluruh

*Penulis Korepondensi

Email Address : wiwiedwijiutami@gmail.com aspek keperibadian dan kehidupan manusia. Menurut UU. No. 20 tahun 2003 tentang Pendidikan disebutkan Pendidikan nasional 
berfungsi mengembangkan kemampuan dan membentuk watak serta peradaban bangsa yang bermartabat dalam rangka mencerdaskan kehidupan bangsa, bertujuan untuk berkembangnya potensi peserta didik agar menjadi manusia yang beriman dan bertakwa kepada Tuhan Yang Maha Esa, berakhlak mulia, sehat, berilmu, cakap, kreatif, mandiri, dan menjadi warga negara yang demokratis serta bertanggung jawab.

Pendidikan adalah usaha sadar dan terencana untuk mewujudkan suasana belajar dan proses pembelajaran agar peserta didik secara aktif dapat mengembangkan potensi dirinya untuk memiliki kekuatan spiritual keagamaan, pengendalian diri, kepribadian, kecerdasan, akhlak mulia, serta keterampilan yang diperlukan dirinya, masyarakat, bangsa dan negara.

Untuk mewujudkan tujuan tersebut, dalam rangka meningkatkan mutu pendidikan diperlukan berbagai upaya aktif dari pendidik untuk mewujudkan pembelajaran yang efektif dan efisien. Sesuai dengan (Permen No. 41 tahun 2007 tentang Standar Proses, Permen No. 16 tahun 2007 tentang Standar Kualifikasi Guru). Proses pembelajaran di kelas akan berhasil jika dalam pelaksanaannya guru memahami dengan baik peran, fungsi dan kegunaan mata pelajaran yang diajarnya. Di samping ketiga hal tersebut, guru juga diharapkan mampu menerapkan berbagai metode ajar sehingga paradigma pengajaran dapat dirubah menjadi paradigma pembelajaran sebagai tuntutan peraturan yang disampaikan pemerintah.

Wardani dan Siti Julaeha (2003 : 22) menjelaskan tujuh syarat keterampilan yang mesti dikuasai guru dalam melaksanakan pembelajaran untuk disebut profesional, yaitu: 1) keterampilan bertanya, 2) keterampilan memberi penguatan, 3) keterampilan mengadakan variasi, 4) keterampilan menjelaskan, 5) keterampilan membuka dan menutup pelajaran, 6) keterampilan membimbing diskusi, dan 7) keterampilan mengelola kelas. Keterampilan-keterampilan ini berhubungan dengan kemampuan guru untuk menguasai dasar-dasar pengetahuan yang dapat memudahkan mereka untuk melakukan persiapan dan pelaksanaan proses pembelajaran untuk memberikan dukungan terhadap cara berpikir siswa yang kreatif dan imajinatif.

Tentunya, keberhasilan pendidikan tidak bisa diupayakan hanya dengan berpangku tangan saja. Sebagai guru harus giat berinovasi dan melakukan pembelajaran secara maksimal. Maka dari itu, seorang guru dituntut keuletan, keilmuan, kemampuan, kecekatan dalam merencanakan dan melaksanakan pembelajaran sesuai keilmuan yang sudah dikuasai agar dapat meningkatkan prestasi belajar siswa.

Prestasi belajar merupakan objek sasaran vital dalam proses kegiatan pembelajaran. Belajar merupakan kegiatan sadar yang dilakukan individu untuk mencapai kemampuan yang baru. Sedangkan pengertian prestasi belajar ialah hasil yang dicapai siswa setelah melakukan perubahan belajar Sudjana (2009 :72). Prestasi belajar ditunjukkan dengan kemampuan siswa mengaplikasikan pengetahuannya dengan sebaik-baiknya dalam kehidupan sehari-hari secara konsisten.

Pada akhir semester ganjil tahun ajaran $2017 / 2018$ didapati bahwa prestasi belajar mata pelajaran Ekonomi siswa kelas XI IPS 1 dikategorikan rendah, yaitu 63,30. Nilai tersebut, masih dibawah dari standar minimal pencapaian mutu pendidikan yang ditetapkan.

Adanya kesenjangan tersebut, mendorong guru melakukan evaluasi pelaksanaan pembelajaran. Sebelumnya, pembelajaran dilakukan menerapkan metode ceramah dan diakhiri dengan pemberian tugas. Kemudian, dalam upaya meningkatkan prestasi belajar siswa, guru mencoba menerapkan strategi pembelajaran Peer Tutorial atau tutor sebaya dan Snowball Throwing dalam pembelajaran. Penerapan strategi tersebut diamati melalui penelitian tindakan kelas atau dikenal dengan istilah Class Action Research.

Strategi pembelajaran merupakan suatu kegiatan pembelajaran yang melibatkan siswa 
dan guru untuk mencapai tujuan pembelajaran secara efektif dan efisien.Sanjaya (2007: 101) Pola umum perbuatan guru dan peserta didik dalam perwujudan kegiatan belajar-mengajar. Lebih lanjut Sanjaya menjelaskan bahwa pola yang dibentuk tersebut berupa urutan atau langkah yang dilakukan oleh guru dan siswa selama proses pembelajaran berlangsung. Dengan demikian bahwa langkah-langkah tersebut dapat berupa metode, model maupun teknik pembelajaran yang sesua dengan tujuan yang akan dicapai.

Keberhasilan suatu program pengajaran tidak disebabkan oleh satu macam sumber daya, tetapi disebabkan oleh perpaduan antara berbagai sumber-sumber daya yang saling mendukung menjadi suatu sistim yang integral.Dalam arti luas sumber belajar tidak harus selalu guru. Sumber belajar dapat orang lain yang bukan guru, melainkan teman dari kelas yang lebih tinggi, teman sekelas, atau keluarganya di rumah. Sumber belajar bukan guru dan berasal dari orang yang lebih pandai disebut tutor. Ada dua macam tutor, yaitu tutor sebaya dan tutor kakak. Tutor sebaya adalah teman sebaya yang lebih pandai, dan tutor kakak adalah tutor dari kelas yang lebih tinggi.

Strategi pembelajaran dengan menggunakan tutor sebaya adalah suatu strategi pembelajaran yang memanfaatkan siswa lain yang memiliki kemampuan lebih tinggi untuk membantu temannya dalam menguasai materi pelajaran yang diajarkan. Siswa yang memiliki kemampuan lebih cepat menyerap materi pelajaran akan membantu siswa yang kurang cepat menyerap materi pelajaran.

Bahasa teman sebaya lebih mudah dipahami, selain itu dengan teman sebaya tidak ada rasa segan, rendah diri, malu, dan sebagainya sehingga diharapkan siswa yang kurang paham tidak segan-segan untuk mengungkapkan kesulitan-kesulitan yang dihadapi Suherman, (2003:277). Diskusi kelompok terbimbing dengan model tutor sebaya merupakan kelompok diskusi yang beranggotakan 5-6 siswa pada setiap kelas di bawah bimbingan guru mata pelajaran dengan menggunakan tutor sebaya. Menurut Ischak dan warji dalam Suherman (2003:276) berpendapat bahwa "Tutor sebaya adalah sekelompok siswa yang telah tuntas terhadap bahan pelajaran, memberi bantuan kepada siswa yang mengalami kesulitan dalam memahami bahan pelajaran yang dipelajarinya". Mengingat bahwa siswa adalah unsur pokok dalam pengajaran yang pada akhirnya dapat mengubah tingkah lakunya sesuai dengan yang diharapkan.

Tutor sebaya merupakan salah satu model pembelajaran kooperatif. Menurut Arends (1997: 111), pembelajaran yang menggunakan model kooperatif memiliki ciri-ciri sebagai berikut: siswa bekerja dalam kelompok secara kooperatif untuk menyelesaikan materi belajar, kelompok dibentuk dari siswa yang memiliki kemampuan tinggi, sedang dan rendah, jika mungkin, anggota kelompok berasal dari ras, budaya, suku, jenis kelamin yang berbedabeda, penghargaan lebih berorientasi pada kelompok dari pada individu (Azizah, 2010: 20). Dengan memanfaatkan cara belajar seperti ini akan dapat membantu mempercepat transformasi pengetahuan yang disampaikan ke seluruh siswa dan dapat membuat siswa belajar lebih giat, lebih aktif, kreatif dan menyenangkan.

Model pembelajaran Tutor Sebaya akan menghidupkan suasana yang kompetitif, sehingga setiap kelompok akan terus terpacu untuk menjadi kelompok yang terbaik. Oleh karena itu, selain aktivitas anggota kelompok, peran ketua kelompok atau tutor sangat besar pengaruhnya terhadap keberhasilan kelompok dalam mempelajari materi ajar yang disajikan. Ketua kelompok dipilih secara demokratis oleh seluruh siswa. Misalnya, jika di suatu kelas terdapat 46 siswa, berarti ada 9 kelompok dengan catatan ada satu kelompok yang terdiri atas 6 siswa.

Sebelum diskusi kelompok terbentuk, siswa perlu mengajukan calon tutor. Seorang tutor hendaknya memiliki kriteria: (1) memiliki kemampuan akademis di atas rata-rata siswa satu kelas; (2) mampu menjalin kerja sama dengan sesama siswa; (3) memiliki motivasi 
tinggi untuk meraih prestasi akademis yang baik; (4) memiliki sikap toleransi dan tenggang rasa dengan sesama; (5) memiliki motivasi tinggi untuk menjadikan kelompok diskusinya sebagai yang terbaik; (6) bersikap rendah hati, pemberani, dan bertanggung jawab; dan (7) suka membantu sesamanya yang mengalami kesulitan (Azizah, 2010: 19).

Menurut Hamalik (1998:163) tahaptahap persiapan dengan menggunakan pendekatan tutor sebaya adalah sebagai berikut: (1) Guru membuat program pengajaran satu pokok bahasan yang dirancang dalam bentuk penggalan-penggalan sub pokok bahasan. Setiap penggalan satu pertemuan yang didalamnya mencakup judul penggalan tujuan pembelajaran, khususnya petunjuk pelaksanaan tugas-tugas yang harus diselesaikan. (2) Menentukan beberapa orang siswa yang memenuhi kriteria sebagai tutor sebaya. Jumlah tutor sebaya yang di tunjuk disesuaikan dengan jumlah kelompok yang dibentuk. (3) Mengadakan latihan bagi para tutor.

Dalam pelaksanaan tutorial atau bimbingan ini, siswa yang menjadi tutor bertindak sebagai guru. Sehingga latihan yang diadakan oleh guru merupakan semacam pendidikan guru atau siswa itu. Latihan di adakan dengan dua cara yaitu melalui latihan kelompok kecil dimana dalam hal ini yang mendapatkan latihan hanya siswa yang akan menjadi tutor, dan melalui latihan klasikal, dimana siswa seluruh kelas dilatih bagaimana proses pembimbingan ini berlangsung. (4) Pengelompokan siswa dalam kelompokkelompok kecil yang yang terdiri atas 4-6 orang. Kelompok ini disusun berdasarkan variasi tingkat kecerdasan siswa. Kemudian tutor sebaya yang telah ditunjuk di sebar pada masing-masing kelompok yang telah ditentukan (Sabarudin, 2009: 13).

Snowball throwing adalah paradigma pembelajaran efektif yang merupakan rekomendasi UNESCO, yakni: belajar mengetahui (learning to know), belajar bekerja (learning to do), belajar hidup bersama (learning to live together), dan belajar menjadi diri sendiri (learning to be) (Depdiknas, 2001:5).

Metode pembelajaran snowball throwing adalah suatu metode pembelajaran yang diawali dengan pembentukan kelompok yang diwakili ketua kelompok untuk mendapat tugas dari guru kemudian masing-masing siswa membuat pertanyaan yang dibentuk seperti bola (kertas pertanyaan) lalu dilempar ke siswa lain yang masing-masing siswa menjawab pertanyaan dari bola yang diperoleh Kisworo dalam Mukhtari, (2010: 6).

Metode snowball-throwing merupakan salah satu modifikasi dari teknik bertanya yang menitikberatkan pada kemampuan meningkatkan motivasi siswa bertanya melalui metode snowball-throwing pertanyaan yang dikemas dalam sebuah permainan yang menarik yaitu saling melemparkan bola salju snowball-throwing berupa kertas yang berisi pertanyaan kepada sesama teman.

Metode yang dikemas dalam sebuah permainan ini membutuhkan kemampuan yang sangat sederhana yang bisa dilakukan oleh hampir setiap siswa dalam mengemukakan pertanyaan sesuai dengan materi yang dipelajarinya. Snowball throwing adalah metode yang digunakan untuk memperdalam satu topik. Metode ini biasa dilakukan oleh beberapa kelompok yang terdiri dari lima sampai delapan orang yang memiliki kemampuan merumuskan pertanyaan yang ditulis dalam sebuah kertas menyerupai bola. Kemudian, kertas itu dilemparkan kepada kelompok lain yang untuk ditanggapi dengan menjawab pertanyaan yang dilemparkan tersebut Jurnal Pendidikan Penabur (Widodo, 2009).

Langkah-langkah yang ditempuh dalam metode ini ialah:

1. Guru menyampaikan materi yang akan disajikan.

2. Guru membentuk kelompok-kelompok dan memanggil masing-masing ketua kelompok 
untuk memberikan penjelasan tentang materi.

3. Masing-masing ketua kelompok kembali ke kelompoknya masing-masing, kemudian menjelaskan materi yang disampaikan oleh guru kepada temannya.

4. Kemudian masing-masing siswa diberikan satu lembar kerja untuk menuliskan

5. pertanyaan apa saja yang menyangkut materi yang sudah dijelaskan oleh ketua kelompok.

6. Kemudian kertas tersebut dibuat seperti bola dan dilempar dari satu siswa ke siswa yang lain selama kurang lebih 5 menit.

7. Setelah siswa mendapat satu bola/satu pertanyaan diberikan kesempatan kepada

8. siswa untuk menjawab pertanyaan yang tertulis dalam kertas berbentuk bola tersebut secara bergantian.

9. Guru memberikan kesimpulan.

10. Guru mengevaluasi kegiatan tersebut dengan cara memberikan komentar sekaligus memberikan penilaian mengenai jenis dan bobot pertanyaan, rumusan

11. kalimat, kemudian memberikan contoh rumusan pertanyaan yang benar.

12. Penutup.

Metode snowball-throwing ini dapat memberikan kesempatan kepada teman dalam kelompok untuk merumuskan pertanyaan secara sistematis. Di samping itu dapat membangkitkan keberanian siswa dalam mengemukakan pertanyaan dengan tuntunan pertanyaan kepada teman lain maupun guru. Juga melatih siswa menjawab pertanyaan yang diajukan oleh temannya dengan baik. Dapat pula merangsang siswa mengemukakan pertanyaan sesuai dengan topik yang sedang dibicarakan dalam pelajaran tersebut. Berikutnya dapat mengurangi rasa takut siswa dalam bertanya kepada teman maupun guru serta melatih kesiapan siswa. Terakhir, dengan menggunakan metode ini memungkinkan siswa saling memberikan pengetahuan.

\section{METODE PENELITIAN}

Penelitian yang dilakukan merupakan penelitian tindakan kelas. Oleh karenanya, rancangan yang khusus untuk sebuah penelitian tindakan sangat diperlukan. Penelitian tindakan didasarkan pada filosofi bahwa setiap manusia tidak suka atas hal-hal yang statis, tetapi selalu menginginkan sesuatu yang lebih baik. Peningkatan diri untuk hal yang lebih baik ini dilakukan terus menerus sampai tujuan tercapai (Suharsimi Arikunto, Suhardjono, Supardi, 2006: 67).

Untuk penelitian ini peneliti memilih rancangan penelitian tindakan yang disampaikan oleh Departemen Pendidikan (2012 :12) seperti terlihat pada gambar berikut.

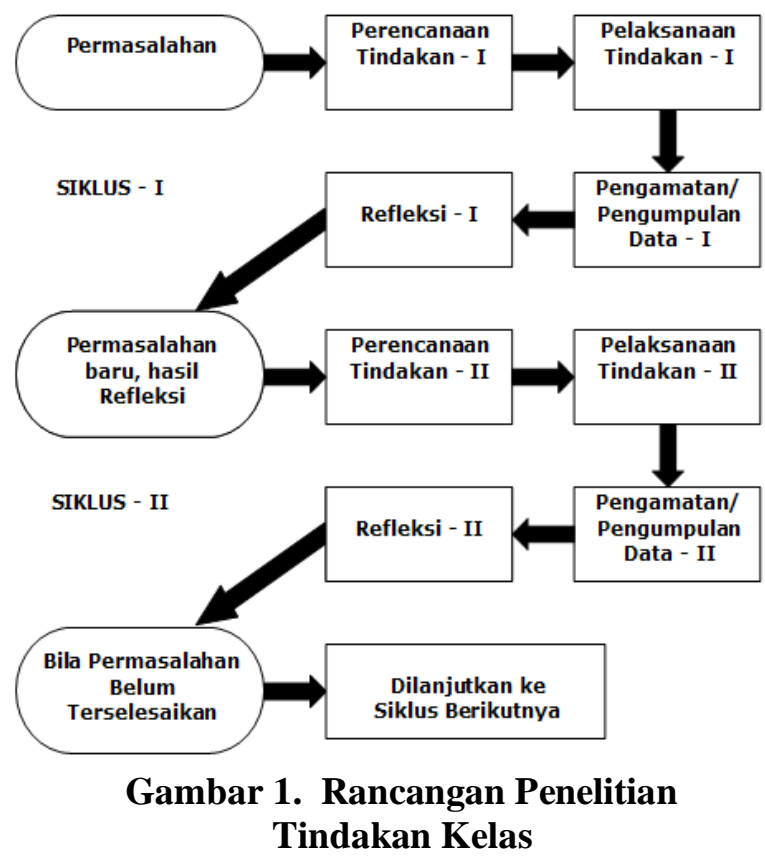

Prosedur yang digunakan sesuai dengan gambar tersebut diatas Dimulai dengan melihat adanya masalah di lapangan. Dengan adanya masalah di lapangan maka peneliti mulai membuat perencanaan I dan selanjutnya melaksanakannya, mengamati atau mengumpulkan data, melakukan refleksi I.

Subjek penelitian ini adalah peserta didik kelas XI IPS 1SMA N 15 Batam yang belajar pada semester ganjil Tahun Pelajaran 2017/2018, yang berjumlah 39 siswa siwi terdiri 19 laki-laki dan 20 perempuan. Objek Penelitian, dalam penelitian ini ialah Peningkatan prestasi belajar siswa kelas XI IPS 1 semester ganjil Tahun Pelajaran 20172018 SMA N 15 Batam. 
Metode pengumpulan data yang digunakan dalam penelitian ini adalah tes prestasi belajar. Tes adalah serangkaian butir pertanyaan yang diberikan kepada peserta tes untuk mengetahui kemampuannya. Metode tes digunakan untuk menilai dan mengukur prestasi belajar siswa terutama aspek kognitif berkenaan dengan penguasaan bahan pengajaran sesuai dengan tujuan pendidikan dan pengajaran. Tes sebagai alat penilaian disusun berupa pertanyaan-pertanyaan yang diberikan kepada siswa untuk mendapatkan jawaban dari siswa dalam bentuk lisa, tulisan atau tindakan ( Sudjana 1989: 35 - 36 ).

Penelitian tindakan kelas yang dilakukan untuk mengetahui sejauh mana tindakan yang diterapkan dapat memberikan dampak setelah dilaksanakan dalam proses pembelajaran, perlu ditentukan batas akhirnya yang disebut indikator keberhasilan. Pada penelitian ini diusulkan siklus I rata-rata nilai siswa sebesar 75 dengan ketuntasan belajar minimal $80 \%$ dan pada siklus II rata-rata nilai siswa sebesar 75 atau lebih dengan ketuntasan belajar minimal $80 \%$ atau lebih.

\section{HASIL DAN PEMBAHASAN}

\subsection{Hasil Penelitian}

Penyampaian hasil penelitian yang telah diperoleh disampaikan secara lengkap dalam paparan di bawah ini.

\subsubsection{Siklus I}

Hasil penelitian di siklus I dapat disampaikan sesuai urutan yang ditegaskan oleh Departemen Pendidikan yaitu dimulai tahap perencanaan, pelaksanaan, observasi dan refleksi, dengan langkah-langkah sebagai berikut

\section{Perencanaan Tindakan I}

Hal-hal yang menjadi perencanaan dari penelitian ini adalah:

Hal-hal yang menjadi perencanaan dari penelitian ini adalah:

1. Melakukan analisis karakteristik siswa untuk menentukan kelompok.
2. Mempersiapkan RPP, Bahan ajar yang akan digunakan dalam tindakan.

3. Melakukan pengecekan mengenai jadwal pelaksanaan penelitian yang telah direncanakan.

4. Menyusun secara rinci skenario tindakan yang telah direncakan dan melakukan pengkajian ulang untuk meminimalisir kemungkinan terjadinya kesalahan.

\section{Pelaksanaan I}

Berikut langkah- langkah penelitian yang telah dilakukan peneliti pada tahap pelaksanaan I :

1. Membawa semua persiapan ke kelas

2. Memasuki kelas dengan mengucapkan salam kepada siswa

3. Sebelum masuk pelajaran inti, guru melakukan apersepsi untuk memancing perhatian siswa terhadap materi pelajaran yang akan disampaikan

4. Mengajar sesuai dengan langkah-langkah penerapan strategi tutor sebaya dan snowball throwing dalam pendalaman topik

5. Mengajak teman guru sejawat ke kelas untuk mengamati kebenaran proses pembelajaran.

6. Memperhatikan kekurangan-kekurangan sebelumnya, dengan giat memperbaiki kekurangan-kekurangan yang sudah ada dalam catatan pelaksanaan pembelajaran sesuai perencanan yang sudah dibuat

7. Mencatat aktivitas belajar siswa

8. Mencatat kreativitas siswa dalam mengikuti pembelajaran

9. Kekurangan/kelemahan metode sebelumnya diperbaiki dengan melaksanakan pembelajaran yang berbasis interaktif mengikuti pendapat-pendapat ahli

10. Memulai pelaksanaan pembelajaran dimulai dengan pendahuluan yaitu: mengucapkan salam, melakukan absensi, memotivasi siswa agar giat belajar, melakukan apersepsi, menyampaikan tujuan pembelajaran serta cakupan materi yang sedang diajarkan.

Pelaksanaan pembelajaran dilakukan dengan giat menuntun siswa, memberi arahan- 
arahan, pada saat ada siswa yang berhasil menjawab pertanyaan dengan benar berupa diberikan penghargaan penguatan verbal. Penggunaan strategi tutor sebaya dan snowball throwing diupayakan secara maksimal sesuai teori-teori yang ada.

Memberi bimbingan dilakukan dengan giat baik secara kelompok maupun secara individual. Contoh-contoh dimaksimalkan agar siswa mampu menangkap materi dengan lebih cepat.

\section{Observasi I}

Observasi dilakukan sebagai upaya mencek sejauhmana penerapan strategi tutor sebaya dan snowball throwing dengan memanfaatkan media secara maksimal untuk dapat meningkatkan kemampuan prestasi belajar peserta didik. Observasi ini dilakukan bersamaan dengan pelaksanaan penelitian dengan cara menilai apa yang bisa dilakukan, melihat apakah peserta didik aktif atau tidak dalam mengikuti proses pembelajaran.

Hasil analisis nilai observasi sikap menunjukan nilai rata-rata atau mean sebesar 72,10. Nilai tersebut masih dibawah Kriteria Ketuntasan Minimal (KKM) yang harus dicapai peserta didik 75. Prosentase ketuntasan minimal sebesar 48,72\%, dengan demikian terdapat 20 peserta didik yang harus diberikan remidi dan pengayaan.

\section{Refleksi I}

Refleksi merupakan kajian secara menyeluruh tindakan yang telah dilakukan berdasar data yang telah terkumpul, kemudian dilakukan evaluasi guna penyempurnaan tindakan. Refleksi menyangkut analisis, sintesis, dan penilaian terhadap hasil pengamatan atas tindakan yang dilakukan (Hopkin, 1993 dalam Suharsimi Arikunto, Sukardjono, Supardi, 2006: 80).

Deskripsi terhadap pelaksanaan penelitian di siklus I ini adalah dari 39 anak yang diteliti, baru 19 orang atau $48.72 \%$ anak yang mampu mencapai ketuntasan belajar sesuai harapan, mereka sudah tidak memerlukan bantuan guru dalam mengerjakan apa yang disuruh. Peningkatan prestasi tersebut sudah sesuai dengan indikator yang dituntut yaitu mencapai nilai rata-rata 72,10 .
Sedangkan anak yang lainnya yang berjumlah 20 orang atau $51,28 \%$ belum mencapai tingkat ketuntasan belajar sesuai harapan. Pelaksanaan pembelajaran pada siklus I ini belum sesuai harapan. Sehingga guru dalam hal ini sebagai peneliti harus giat memotivasi anak agar lebih giat dan lebih kreatif.

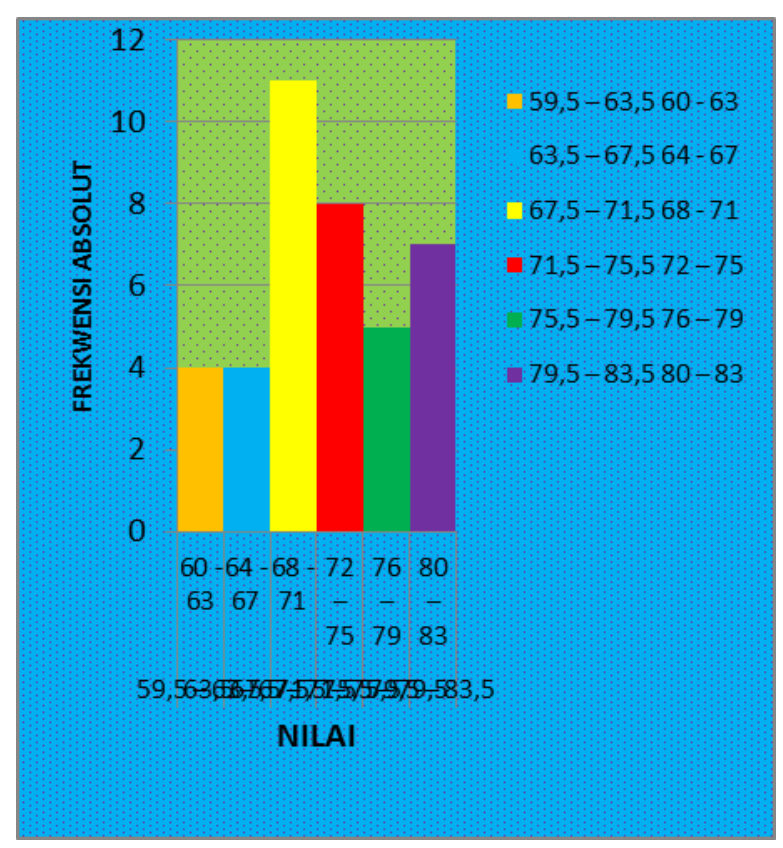

Gambar 2. Grafik Siklus I Prestasi Belajar Ekonomi Peserta Didik kelas XI IPS 1

Dari gambar grafik histogram di atas dapat jelaskan bahwa pada siklus 1 ini siswa yang mendapat nilai 60-63 sebanyak 4 siswa, yang mendapatkan nilai $64-67$ sebanyak 4 siswa, yang mendapat nilai 68 -71 sebanyak 11 siswa,yang mendapat nilai $72-75$ sebanyak 8 orang, yang mendapatkan nilai $76-79$ sebanyak 5 siswa dan yang mendapatkan nilai 79 - 83 sebanyak 7 siswa.

Sintesis yang dapat disampaikan adalah dari 39 siswa yang diteliti ternyata hasilnya belum sesuai dengan harapan. Masih tercermin dengan jelas kemampuan peserta didik terhadap materi yang diajarkan belum mampu diresapkan dengan baik. Pencapaian pada siklus ini dapat disampaikan, yaitu 48,72\% anak ada diatas KKM 51,28\% yang masih dibawah KKM. Dari pencapaian data tersebut ternyata keberhasilan yang diperoleh pada siklus I belum terpenuhi. Indikator pencapaian yang diharapkan belum terpenuhi yaitu $48,72 \%$ atau lebih siswa sudah mencapai 
nilai diatas KKM. Karena itu penelitian harus dilanjutkan ke siklus berikutnya.

\section{Penilaian Siklus I}

Sesuai fakta yang berhasil ditemui di lapangan, pada Siklus I ini ditemukan beberapa kekurangan-kekurangan dan kelebihan-kelebihan sebagai berikut :

Kekurangan-kekurangan yang ditemukan:

1. Jumlah kelompok terlalu besar, pelaksanaan pembelajaran membutuhkan waktu yang lama karena media yang dibuat belum memenuhi kriteria untuk mewakili keinginan siswa.

2. Ikatan pertemanan belum terjalin erat sehingga menjadi penghambat dalam menumbuhkan motivasi, keyakinan dan keberanian dalam diri peserta didik.

3. Guru belum menemukan cara untuk menumbuhkan ikatan emosi dengan cepat agar peserta didik mampu menguasai materi yang disampaikan dan mampu menerapkannya dalam kehidupan seharihari.

4. Penyajian yang dilakukan belum maksimal karena peneliti baru mencoba model yang digunakan.

Kelebihan yang ada adalah:

1. Peneliti telah berupaya dengan sebaikbaiknya untuk menyiapkan bahan pembelajaran agar perkembangan peserta didik membaik.

2. Pengelolaan kelas sudah diupayakan dan bimbingan terhadap siswa juga sudah dilakukan dengan maksimal.

3. Untuk validasi data, guru telah mengajak teman sejawat untuk mengamati proses pembelajaran.

Kekurangan-kekurangan yang telah disampaikan itu akan dibenahi selanjutnya pada Siklus II. Demikian penilaian yang bisa disampaikan untuk memberikan deskripsi terhadap kebenaran perolehan data di siklus I.

\subsubsection{Siklus II}

\section{Perencanaan II}

Rencana yang dibuat pada siklus II sama dengan rencana tindakan siklus I yaitu :
1. Mengecek jadwal yang yang telah ditentukan;

2. Mengecek kekurangan-kekurangan sebelumnya seperti jumlah anggota kelompok terlalu banyak;

3. Berkonsultasi dengan teman-teman guru tentang penggunaan strategi tutor sebaya dan snowball throwing;

4. Menyusun rencana dalam mengatasi masalah yang ada :

a. Masalah kurangnya semangat siswa dalam berdiskusi diperbaiki dengan cara memberikan hadiah bagi kelompok yang terbaik;

b. Kekurangan dalam pembagian anggota kelompok yang terlalu banyak diupayakan diatasi dengan mengurangi jumlah anggota kelompok;

5. Menyusun RPP mengikuti alur strategi tutor sebaya dan snowball throwing

\section{Pelaksanaan II}

Pelaksanaan penelitian di siklus II juga dilakukan sebanyak 3 kali pertemuan, sama dengan pelaksanaan penelitian pada siklus salam, berlanjut dengan memberi penjelasan I. Perbaikan pelaksanaan dilakukan dengan melaksanakan perbaikan fokus pada perbaikan yang tercantum pada perencanaan dengan harapan pelaksanaan perbaikan ini mampu meningkatkan kemampuan mereka.

1. Masuk ke kelas dengan membawa lembar observasi/pengamatan

2. Masuk ke kelas dengan mengucapkan tentang tes yang harus dikerjakan, membagikan tes serta lembar kertas yang digunakan untuk menjawab soal-soal tes pada siswa

3. Memberi kesempatan pada siswa untuk menandatangani absen kehadiran ikut tes

4. Mengawasi pelaksanaan tes agar siswa tidak bekerjasama untuk memperoleh data yang valid atau dapat dipertanggungjawabkan keabsahannya.

5. Setelah waktu pengerjaan tes berakhir, dilanjutkan dengan mengumpulkan jawaban peserta didik yang menyampaikaneberapa hal yang perlu dilakukan selanjutnya. 
6. Penyampaian pada peserta didik, bahwa setelah jawaban mereka diperiksa, hasilnya akan dibagikan pada mereka dan menjelaskan; bagi mereka yang nilainya belum mencapai KKM yang sudah ditentukan, maka akan diberikan remedial dan bagi yang sudah mencapai KKM atau melebihi akan diberikan pengayaan.

Hasil observasi yang sudah dilakukan pada siklus II menunjukkan bahwa capaian ketuntasan sebesar $89,74 \%$, dengan nilai ratarata diatas KKM yaitu 83,20. Dengan demikian masih ada 4 peserta didik yang harus diberikan pengayaan dan remidi.

\section{Refleksi II}

Berdasarkan hasil observasi atau pegamatan data yang dilakukan pada anakanak yang diteliti dapat dijelaskan bahan mereka yang meningkat sesuai harapan. Refleksi terhadap hasil pengamatan yang diperoleh adalah dari 39 orang anak yang diteliti ternyata $35(89,74 \%)$ sudah mampu meningkatkan prestasi belajarnya. Hal tersebut menunjukkan bahwa mereka sudah berkembang melebihi indikator yang dituntut. Dari kegiatan pembelajaran setelah diamati, semua anak sudah menyertakan hasil pekerjaannya. Mereka sudah dipacu dengan apa yang telah dihasilkan oleh temantemannya. Kesimpulan refleksinya adalah bahwa peningkatan prestasi belajar siswa sudah berkembang dengan baik

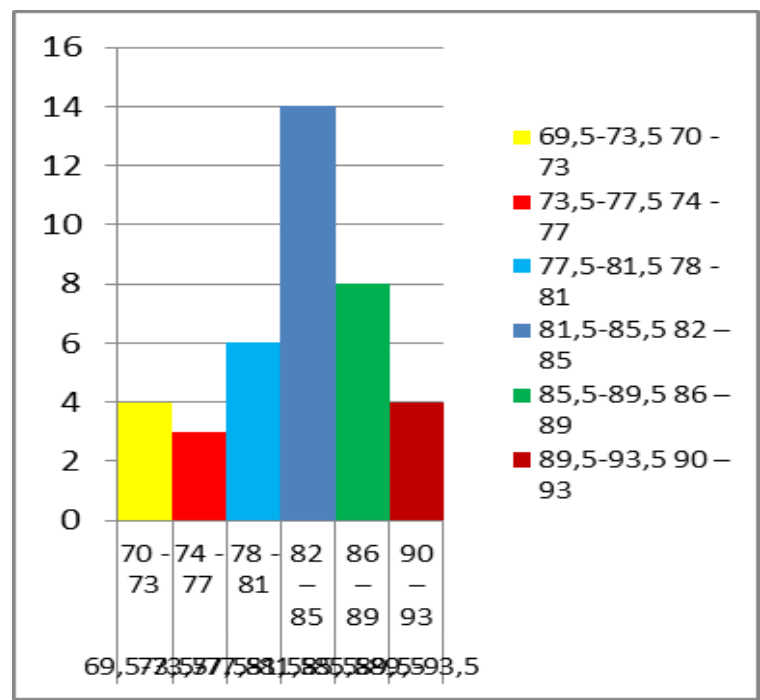

Gambar 3.Grafik Siklus II Prestasi Belajar Ekonomi Peserta Didik kelas XI IPS 1
Berdasarkan Gambar 2 dapat dijelaskan bahwa setelah dilakukan penelitian siklus ke II ternyata yang mendapatkan nilai $70-73$ sebanyak 4 orang, yang mendapatkan nilai $74-77$ sebanyak 3 orang, yang mendapatkan nilai $78-81$ sebanyak 6 orang, yang mendapat nilai $82-85$ sebanyak 14 siswa, yang mendapat nilai $86-89$ sebanyak 8 orang dan yang mendapatkan nilai $90-93$ sebanyak 4 siswa.

\section{Sintesis}

Sesuai pendapat ahli yang telah disampaikan di awal penulisan refleksi, bahwa dalam refleksi dilakukan analisis, sintesis dan penilaian/evaluasi, sehingga pada bagian ini perlu disajikan hal-hal tersebut. Sintesis artinya campuran berbagai pengertian sehingga merupakan kesatuan yang selaras. Artinya semua data yang sudah dianalisis, baik proses pembelajaran, keaktifan belajar maupun hasil yang diperoleh dari prestasi belajar disatukan dan dicoba diberi gambaran.

Sintesa yang dpat diberikan adalah dari 39 anak yang diteliti ternyata hasilnya sudah sesuai dengan harapan, motivasi sudah dimaksimalkan, arahan-arahan sudah optimal, pemusatan perhatian siswa terhadap materi yang diajarkan diupayakan sangat mantap, berbagai metode ajar sudah diupayakan secara bervariasi. Perolehan hasilnya $89,74 \%$ siswa sudah mencapai ketuntasan belajar yang dituntut dalam indikator keberhasilan penelitian.

\section{Penilaian Siklus II}

Penilaian yang dapat diberikan terhadap pelaksanaan Siklus II ini yaitu pembelajaran telah tuntas dapat dilaksanakan. Semua kekurangan-kekurangan yang ada sudah diperbaiki pada siklus ini, sehingga tidak perlu lagi ada keragu-raguan bahwa strategi tutor sebaya dan snowball throwing mampu meningkatkan prestasi belajar sesuai harapan. Indikator yang dituntut untuk diselesaikan tidak ada lagi yang tertinggal. Semua hasil yang diperoleh pada Siklus II ini menunjukkan bahwa penelitian ini tidak perlu dilanjutkan lagi ke siklus berikutnya. 
Kelebihan dan kelemahan pelaksanan siklus II dapat dijelaskan sebagai berikut:

Kelebihan-kelebihan:

1. Persiapan pembelajaran dengan metode ini sudah lebih matang.

2. Penyajian yang dilakukan sudah lebih maksimal karena peneliti sudah beberapa kali menggunakan model pembelajaran snowball trowing ini.

3. Pelaksanaan pembelajaran dengan metode ini lebih efektif dan efisien karena siswa sudah menguasai strateginya, selain itu jumlah anggota perkelompok juga sudah standart.

4. Siswa lebih semangat dan lebih antusias dalam proses pelaksanaan belajar karena metodenya sangat menyenangkan dan ikatan pertemanan perkelompoknya sudah sangat erat.

Kelemahan-kelemahan:

1. Jika siswa yang telah ditunjuk sebagai tutor sebaya dalam kelompok tersebut tidak fokus dan kurang pandai menyampaikan penjelasan materinya maka anggota kelompoknya akan bingung.

2. Bagi siswa yang kurang fokus maka siswa tidak akan bisa membuat pertanyaanpertanyaan juga menjawab pertanyaan dari temannya sesuai materi yang sudah dijelaskan sama tutor pada kelompoknya.

\subsection{Pembahasan}

Perolehan hasil dari kegiatan penelitian pada siklus II ini terbukti telah menunjukkan bahwa kemampuan siswa dalam mengikuti pelajaran sudah cukup baik. Ini terbukti dari rata-rata nilai siswa mencapai 83,20 dengan ketuntasan belajar $89,74 \%$. Hasil ini menunjukkan bahwa strategi tutor sebaya dan snowball throwing telah berhasil meningkatkan kemampuan siswa menempa ilmu sesuai harapan. Strategi tutor sebaya dan snowball throwing merupakan strategi yang cocok bagi siswa apabila guru menginginkan mereka memiliki kemampuan melakukan analisis, sintesis, berargumentasi, mengeluarkan pendapat secara lugas.

\subsubsection{Gambaran Pelaksanaan Pra Siklus}

Deskripsi awal telah menunjukkan rendahnya prestasi belajar siswa yang diakibatkan oleh faktor-faktor luar dan faktorfaktor dari dalam diri guru sendiri. Faktorfaktor tersebut telah dipahami betul dan pelanpelan diperbaiki agar proses pembelajaran tidak dipengaruhi oleh faktor-faktor tersebut dengan cara membuat perencanaan yang lebih baik pada siklus berikutnya. Dari faktor siswa tentang kurangnya motivasi orang tua dalam mengarahkan anak-anak mereka untuk mau giat belajar dilakukan dengan memberi pengarahan lewat penyampaian yang dilakukan kepala sekolah terhadap orang tua siswa.

\subsubsection{Pembahasan Hasil yang Diperoleh dari Siklus I}

Dari hasil pengamatan yang telah dilakukan pada siklus I ini dalam upaya pembenahan proses pembelajaran di kelas dapat disampaikan bahwa ada kelebihankelebihan yaitu peneliti telah membuat perencanaan yang matang, dengan terlebih dahulu membaca teori yang ada, dalam pelaksanaan pembelajaran peneliti sudah berpakaian rapi, menggunakan bahasa yang santun, menuntun siswa dengan baik. Hal ini menimbulkan interpretasi bahwa proses penelitian berjalan cukup baik.

Kelemahan yang ditemukan ialah perlu diberikan analisis yaitu penggunaan waktu yang belum efektif, konstruksi, kontribusi siswa belum maksimal, fakta ini akan dijadikan acuan kebenaran data, validasi internal validitas eksternal berupa penggunaan teori-teori yang mendukung dan reliabilitas data penelitian ini dapat penulis yakini karena hal itu merupakan ketepatan peneliti memilih instrumen. Faktor-faktor yang berpengaruh belum maksimalnya pembelajaran pada siklus I ini adalah karena peneliti baru satu kali mencoba model ini. Cara pemecahan masalahnya adalah penyiapan RPP yang lebih baik, lebih berkualitas, meminta pendapat 
teman sejawat untuk memperoleh tambahan pengalaman, gambaran-gambaran.

Dari gambaran pelaksanaan yang telah dilakukan ternyata hasil yang diperoleh pada siklus I ini sudah lebih baik dari hasil awal yang baru mencapai nilai rata-rata 68,41 dengan ketuntasan belajar 33,33\%. Pada siklus I ini sudah mencapai peningkatan sedikit lebih tinggi yaitu dengan rata-rata 72,10 dan ketuntasan belajar $48,72 \%$ Namun hasil tersebut belum maksimal karena tuntutan indikator keberhasilan penelitian adalah agar peserta didik mampu memperoleh rata-rata 83,20 dengan ketuntasan belajar 89,74\% Oleh karenanya penelitian ini masih diperlukan tindak lanjut.

\subsubsection{Pembahasan Hasil yang Diperoleh dari Pelaksanaan Siklus II}

Perolehan hasil dari kegiatan penelitian dari tahap awal, siklus I dan siklus II sebagai berikut :

Tabel 1.Tabel prestasi belajar ekonomi peserta didik

\begin{tabular}{|c|c|c|}
\hline No & Tahapan & Prestasi Belajar \\
\hline 1 & Tahap awal & 68,41 \\
\hline 2 & Siklus 1 & 72,1 \\
\hline 3 & Sikulus 11 & 83,2 \\
\hline
\end{tabular}

Tabel prestasi belajar tersebut di atas dapat disajikan dalam bentuk grafik sebagai berikut

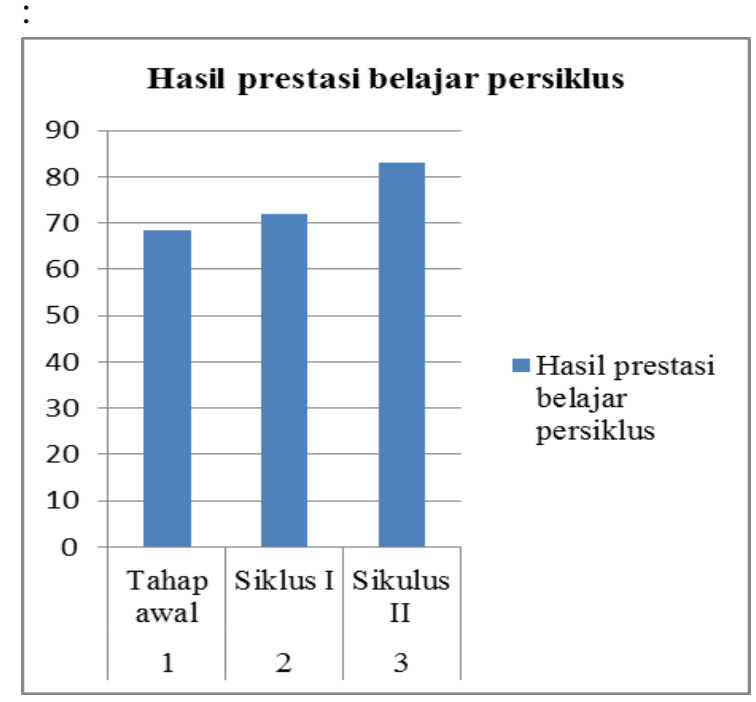

Gambar 4. Grafik Hasil Prestasi Belajar Ekonomi Peserta Didik
Perolehan hasil dari kegiatan penelitian dari tahap awal, siklus 1 dan siklus II ini terbukti telah menunjukkan bahwa kemampuan siswa dalam mengikuti pelajaran sudah cukup baik. Ini terbukti dari rata-rata nilai siswa mencapai 83,20 dengan ketuntasan belajar $89,74 \%$. Hasil ini menunjukkan bahwa strategi tutor sebaya dan snowball throwing telah berhasil meningkatkan kemampuan siswa menempa ilmu sesuai harapan. Strategi tutor sebaya dan snowball throwing merupakan metode/model yang cocok bagi siswa apabila guru menginginkan mereka memiliki kemampuan melakukan analisis, sintesis, berargumentasi, mengeluarkan pendapat secara lugas. Strategi tutor sebaya dan snowball throwing mampu memupuk kemampuan intelektual siswa, mendorong siswa untuk mampu menemukan sendiri, menempatkan siswa pada posisi sentral dan mengupayakan agar siswa mampu belajar lewat penemuan agar materi yang dipelajari dapat diingiat lebih lama.

Hasil penelitian ini ternyata telah memberi efek utama bahwa model yang diterapkan dalam proses pembelajaran berpengaruh secara signifikan terhadap prestasi belajar siswa. Temuan ini membuktikan bahwa guru sudah tepat memilih metode dalam melaksanakan proses pembelajaran karena pemilihan metode merupakan hal yang tidak boleh dikesampingkan. Hal ini sejalan pula dengan temuan-temuan peneliti lain seperti yang dilakukan oleh Inten dan Puger (2004) yang pada dasarnya menyatakan bahwa metode pembelajaran yang diterapkan berpengaruh terhadap prestasi belajar siswa.

Upaya maksimal dalam melaksanakan pembelajaran pada siklus II dengan memperbaiki semua kelemahan-kelemahan sebelumnya telah mampu membuat peningkatan pemahaman dan keilmuan peserta didik. Dari nilai yang diperoleh siswa, lebih setengah siswa mendapat nilai 80, 36 siswa memperoleh nilai sesuai KKM dan 4 siswa memperoleh nilai rendah. Atas dasar perolehan data dalam bentuk nilai tersebut dapat diyakini bahwa prestasi belajar siswa dapat ditingkatkan 
dengan strategi tutor sebaya dan snowball throwing.

Melihat perbandingan nilai awal, nilai siklus I dan nilai siklus II, terjadi kenaikan yang signifikan, yaitu dari rata-rata nilai awal adalah 68,41 naik di siklus I menjadi 72,10 dan di siklus II naik menjadi 83,20. Kenaikan ini tidak bisa dipandang sebelah mata karena kenaikan nilai ini adalah dari upaya-upaya yang maksimal yang dilaksanakan peneliti demi peningkatan mutu pendidikan dan kemajuan pendidikan khususnya di SMA N 15 Batam.

\section{KESIMPULAN DAN SARAN}

\subsection{Kesimpulan}

Berdasarkan penelitian yang telah dilaksanakan maka kesimpulan yang dapat disampaikan berdasarkan semua hasil analisis data yang telah dilakukan dengan melihat hubungan rumusan masalah, tujuan penelitian, hipotesis tindakan dan semua hasil pembahasan adalah sebagai berikut:

1. Dari hasi analisis yang telah dilakukan yang dilanjutkan dengan pembahasan dapat disampaikan bahwa peningkatan hasil belajar telah dapat diupayakan. Dari data awal yang rata-rata baru mencapai 68,41 dan jauh dari kriteria ketuntasan minimal pada mata pelajaran ini, pada siklus I sudah dapat ditingkatkan menjadi 72,10 dan pada siklus II sudah mencapai rata-rata 89,74. Siswa yang pada awalnya kemampuannya masih sangat rendah dimana hanya ada 13 yang tuntas, pada siklus I sudah dapat ditingkatkan yaitu ada 19 siswa yang sudah tuntas dan pada siklus II sudah 35 yang tuntas. Dari hasil awal ada 26 siswa yang harus diremidi sedangkan pada siklus II hanya 4 siswa yang mesti diremidi.

2. Dari uraian fakta-fakta dan hasil observasi siklus I dan siklus II yang telah diuraikan diatas, membuktikan bahwa penerapan strategi tutor sebaya dan snowball throwing. Dengan hasil tersebut dapat dibuktikan bahwa rumusan masalah dan tujuan penelitian telah tercapai dan hipotesis yang diajukan sudah dapat diterima. Untuk hal tersebut selanjutnya perlu disampaikan saran.

\subsection{Saran}

Berdasarkan temuan yang sudah disimpulan dari hasil penelitian, dalam upaya mencapai tujuan pembelajaran, dapat disampaikan saran-saran sebagai berikut :

1. Bagi guru, metode tutor sebaya dan snowball throwing dapat menjadi alternatif metode pembelajaran untuk diterapkan dalam pembelajaran, mengingat metode ini telah terbukti dapat meningkatkan kualitas pembelajaran.

2. Bagi peneliti lain, walaupun penerapan strategi tutor sebaya dan snowball throwing

3. Sudah terbukti meningkatkan prestasi belajar, tentunya penelitian ini membutuhkan penyempurnaan, misalnya dapat ditambahkan dengan media belajar tertentu.

\section{UCAPAN TERIMAKASIH}

Penulis mengucapkan terimakasih kepada kedua orangtua, keluarga, almamater, kepala sekolah, peserta didik, dan Nova Puji, S.Pd. sebagai guru kelas 4 SD Kanaan Ungaran, serta dosen pembimbing Dr. Mawardi, M.Pd dan Krisma Wardani, S.Pd., M.Pd.

\section{REFERENSI}

Anastasi, Anne. 1976. Psychological Testing. Fifth Edition. New York: Macmillan Publishing Co., Inc.

Arikunto, Suharsimi; Suhardjono; Supardi. 2006. Penelitian Tindakan Kelas. Jakarta: PT Bumi Aksara.

Aryana, Wayan. 2003. Pengaruh Motivasi Belajar terhadap Prestasi Belajar IPA pada Siswa SMP Negeri 1 Denpasar. Ringkasan Hasil Penelitian yang Disampaikan dalam Seminar Hasil Penelitian Dosen Kopwil VIII, Tanggal 22-24 September 2003. 
Azizah, Rizka. 2010. Skripsi. Pengaruh Model Pembelajaran Tutor Sebaya Terhadap Hasil Belajar Matematika. Jurusan Pendidikan Matematika Fakultas Ilmu Tarbiyah Dan Keguruan Universitas Islam Negeri Syarif Hidayatullah Jakarta.

Azwar, Saifuddin. 2003. Penyusunan Skala Psikologi. Yogyakarta: Pustaka Pelajar.

Dahar, Ratna Wilis. 1989. Teori-Teori Belajar. Jakarta: Penerbit Erlangga.

Depdikbud. 1984/1985. Program Akta Mengajar V-B Komponen Dasar Kependidikan: Penilaian Program Pendidikan. Jakarta: Universitas Terbuka.

Depdikbud. 1994. Petunjuk Pelaksanaan Proses Belajar-Mengajar. Jakarta: Direktorat Pendidikan Menengah Umum.

Depdikbud. 1996. Petunjuk Teknis Mata Pelajaran IPS-Sejarah. Jakarta: Direktorat Pendidikan Menengah Umum.

Depdiknas. 2011. Membimbing Guru dalam Penelitian Tindakan Kelas. Jakarta: Pusat Pengembangan Tenaga Kependidikan, Badan Pengembangan Sumber Daya Manusia Pendidikan dan Penjaminan Mutu Pendidikan.

Dimyati dan Mudjiono. 2001. Belajar dan Pembelajaran. Jakarta: Dirjen Dikti.

Djamarah, Syaful Bahri. 2002. Prestasi Belajar dan Kompetensi Guru. Surabaya: Usaha Nasional.

Gagne, Robert M. 1977. The Conditions of Learning. Third Edition. New York: Holt, Reinhart and Winston.

Hamalik, Oemar. 2002. Psikologi Belajar dan Mengajar. Bandung: Sinar Baru.

Herrhyanto, Nar dan Hamid, Akib. 2006. Statistika Dasar. Jakarta: Universitas Terbuka.

Hilke, Eileen Veronica. 1998. Fastback Cooperative Learning. New York: McGraw-Hill, Inc.

Inten, I Gede. 2004. Pengaruh Model Pembelajaran dan Pengetahuan Awal
Siswa Terhadap Prestasi Belajar PKn dan Sejarah pada Siswa Kelas II di SMU Laboratorium IKIP Negeri Singaraja. Tesis. Program Pascasarjana IKIP Negeri Singaraja.

Lickona, Thomas. 1992. Educating For Character. How Our Schools Can Teach Respect and Responsibility. New York: Bantam Books.

Lie, Anita. 2002. Cooperative Learning: Mempraktikkan Cooperative Learning di Ruang-Ruang Kelas. Jakarta: PT Gramedia Widiasarana Indonesia.

Miles, Matthew, B. Dan A. Michael Hubberman. 1992. Analisis Data Kualitatif. Terjemahan Tjetjep Roheadi Rohidi. Jakarta: Penerbit Universitas Indonesia.

Murwansyah dan Mukaram. 2002. Manajemen Sumber Daya Manusia. Bandung: Pusat Penerbit Administrasi Niaga Politeknik Negeri Bandung, Indonesia.

Nana Sudjana. 2000. Metode penelitian Pendididikan. Bandung : Rosdakarya

Nasution, S. 1972. Didaktik Sekolah Pendidikan Guru: Asas-Asas Didaktik Metodologi Pengajaran dan Evaluasi. Depdikbud: Jakarta.

Nur, Mohamad et al. 2001. Teori Belajar. Surabaya: University Press.

Peraturan Menteri Pendidikan Nasional No. 41 Tahun 2007 Tanggal 23 November 2007. Jakarta: Depdiknas.

Popham, W. James dan Eva L. Baker. 1984. Bagaimana Mengajar Secara Sistematis. Diterjemahkan Oleh R.H. Dj. Sinurat et al. Yogyakarta: Kanisius.

Puger, I Gusti Ngurah. 2004. Pengaruh Model Pembelajaran dan Kemampuan Berpikir Silogisme Terhadap Prestasi Belajar Biologi Pada Siswa Kelas III SMP Negeri Seririt (Experimen Pada Pokok Bahasan Reproduksi Generatif Tumbuhan Angiospermae). Tesis. Singaraja: IKIP Negeri Singaraja.

Riyanto, H. Yatim. 2009. Paradigma Biru Pendidikan. Jakarta: Fajar Interpratama Offset. 
Saifudin Sau'd, Udin. 2008. Inovasi Pendidikan. Bandung: Alfabeta.

Sardiman, A.M. 1988. Interaksi dan Motivasi Belajar-Mengajar Pedoman bagi Guru dan Calon Guru. Jakarta: Rajawali Pers.

Silverius, Suke. 1991. Evaluasi Hasil Belajar dan Umpanbalik. Jakarta: PT Grasindo.

Slamet, PH. 2004. MBS, Life Skill, KBK, CTL dan Saling Keterkaitannya. Makalah yang Disampaikan pada Semiloka DBEP di NTB dan Bali.

Slameto. 2000. Belajar dan Faktor-Faktor yang Mempengaruhinya. Jakarta: Rineka Cipta.

Slavin, Robert E. 1995. Cooperative Learning : Theory, Research, and Practice. Boston: Allyn and Bacon.

Soedomo, M. 2001. Landasan Pendidikan. Malang: Penyelenggaraan Pendidikan Pascasarjana Proyek Peningkatan Perguruan Tinggi.

Soemanto, Wasty. 2001. Pengantar Psikologi Pendidikan. Surabaya: Usaha Nasional.

Soetomo. 1993. Dasar-Dasar Interaksi Belajar-Mengajar. Surabaya: Usaha Nasional.

Sudijono, Anas. 2001. Pengantar Evaluasi Pendidikan. Jakarta: Rajawali Pers.

Sudijono, Anas. 2001. Pengantar Statistik Pendidikan. Jakarta: Rajawali Pers.

Sudjana, Nana. 2002. Penilaian Hasil Proses Belajar Mengajar. Bandung: PT Remaja Rosdakarya.

Sudjana. 1996. Metoda Statistika. Bandung: Tarsito.

Sukidin, Basrowi, Suranto. 2002. Menajemen Penelitian Tindakan Kelas. Penerbti: Insan Cendekia ISBN: 9799048334.

Supardi, 2005. Pengembangan Profesi dan Ruang Lingkup Karya Ilmiah. Jakarta: Depdiknas.
Suryabrata, Sumadi. 2000. Pengembangan Alat Ukur Psikologis. Yogyakarta: Penerbit Andi.

Trianto. 2010. Mengembangkan Model Pembelajaran Tematik. Jakarta: Prestasi Pustaka.

Uno, B. Hamzah, et. al. 2001. Pengembangan Instrumen Untuk Penelitian. Jakarta: Delima Press.

Wardani, I. G. A. K \& Siti Julaeha. 2003. Modul IDIK 4307. Pemantapan Kemampuan Mengajar. Jakarta: Universitas Terbuka.

Wijaya, F. A., Mawardi, M., \& Wardani, K. W. 2018. Upaya Peningkatan Hasil Belajar Menggunakan Group Investigation Pada Siswa Kelas 4 Sekolah Dasar. Widyagogik: Jurnal Pendidikan dan Pembelajaran Sekolah Dasar, 5(2), 149-159

Wulandari, Fitria.2016.Penerapan Model Pembelajaran Inkuiri Terbimbing untuk Meningkatkan Hasil Belajar IPA Siswa Sekolah Dasar.Sidoarjo:Vol. 5, No 2.

Yaumi, Mohammad.2014. Prinsip-prinsip design pembelajaran.Jakarta: Kencana 